\title{
Career Opportunity for Ghanaian Youth: An Evaluation of Jewellery Subject under Visual Art Programme in Senior High Schools in Ghana
}

\author{
Mohammed Kwaku Baidoo \\ Kwame Nkrumah University of Science and Technology, Kumasi, Ghana \\ E-mail: mkbaidoo@knust.edu.gh
}

Received: 12 January 2021; Revised: 12 March 2021; Accepted: 25 March 2021

\begin{abstract}
The purpose of the study was to evaluate the Jewellery subject in Senior High Schools in Ghana to ascertain the career opportunity in jewellery for Ghanaian youth. The study adopted the Mixed Methods Research approach with descriptive and document analysis as the research method used. The findings of the study show that jewellery students are not able to practise as jewellers after their studies, because the content of the jewellery subjects and its associated exercises does not correspond to the skills one is required to become a jeweller. Coupled with the fact that the teachers who teach the jewellery are mostly not professional jewellers, which therefore limit the kind of practical jewellery that they can teach the students. Although the motivating factor for introducing jewellery is good, however, the rhetorics of the government that she wants students to acquire skills in jewellery making does not support the reality on the ground.
\end{abstract}

Keywords: career development, career pattern, visual art, vocational education, jewellery, jewellery education, jewellers

\section{Introduction}

Jewellery education just as any other vocation can be acquired through either school-based or apprenticeship in Ghana. Fening (2015) postulates that school-based jewellery education (Gold/Silversmith) in Ghana started at the tertiary level in Kwame Nkrumah University of Science and Technology, Kumasi in 1968 whiles at the second cycle level, it has begun 1990 in the then Labone Secondary School. Since then many other schools at both the second cycle and tertiary levels in Ghana have introduced jewellery into their programmes of study. Statistical data which are available give the indication that jewellery apprenticeship commands about 80 to $90 \%$ of trained jewellers in Ghana (Atchoarena \& Delluc, 2001). In recent times the story is different as the patronage of apprenticeship in jewellers keeps declining (Kotoku, 2009; Fening \& Asomaning, 2014).

To rejuvenate this and other known vocational trainings that are traditionally associated with Ghanaians, Ghana, after 17 years of practicing the education system which was geared toward training of the administrator by her colonial master's (British) subsequent to independence, realised that as a nation she is gifted with a lot of resources. Nevertheless, the country does not harness the full potential benefits of the resources for her citizens. This is because the country exports about $90 \%$ of the natural resources without value addition. To reverse this trend then the first president of Ghana in outlining his policy on education for new Ghana on 5th March, 1957 to the Legislative Assembly, Osagyefo Kwame Nkrumah said that:

Copyright (C2021 Mohammed Kwaku Baidoo

DOI: https://doi.org/10.37256/ser.222021767

This is an open-access article distributed under a CC BY license

(Creative Commons Attribution 4.0 International License)

https://creativecommons.org/licenses/by/4.0/ 
Our whole educational system must be geared to producing a scientifically-technically minded people. Because of the limitations placed on us, we have to produce, of necessity, a higher standard of technical education than is necessary in many of the most advanced countries of the Western world. (McWilliam \& Kwamena-Poh, 1975)

This was reaffirmed in the Education Act (2008) where the preamble of the act states that:

An act to provide for establishment of an educational system intended to produce well-equipped individuals with the requisite knowledge, skills, values, attitudes and aptitudes to become functional and productive citizens for total development and the democratic advancement of the nation and for related matters.

In line with this, the country has embarked on major transformation of her educational system from that of the colonial master. In this regard, a number of educational reforms and reviews have taken place. Among them are Education Reform in 1974 led by Dzobo, Evans-Anfom 1987 Reform and that of Anamuah-Mensah in 2007 (Poku, 2013). Proponents of these reforms contended that human capital development is required to the growth and development process of any successful country, hence, these reforms. It is gratifying to note that reasons for undertaking the reforms are not much different; implementation of the recommendations of the various reform committees has remained to be a challenge, hence, these diverse reforms.

Some of the outcomes of these reforms include the structure of the education system in Ghana and the introduction of Science, Technical and Vocational programmes (Adams, 2008). One of the programmes that was introduced under the Vocational Education programme is Visual Arts. In the early 1990s the Curriculum Research and Development Division (CRDD) of the Ministry of Education introduced Jewellery as one of the elective subjects under Visual Arts Programme of Senior High School (SHS).

Among the rationales for introducing the jewellery subject is to train students as jewellers with the necessary knowledge and skills to fill the gap of manpower in the jewellery making sector (CRDD, 2008). The motivation behind the introduction of jewellery in the SHS programme is good, however the majority of students who study SHS jewellery are not able to practise as jewellers after their secondary education. This has been attributed to the fact that the content of the jewellery subjects and its associated exercises does not correspond to what pertain to the Jewellery Industry. Aside that the teachers who teach jewellery at the Senior High Schools are mostly not professional Jewellers, and therefore are limited with the kind of practical jewellery that they can teach the students. Looking at the country as the second largest producer of gold in Africa, the country produces over 2.5 million ounces of gold annually for which about $90 \%$ of them are exported in the raw state without value addition, which makes the country earn less revenue from the raw gold export (Moran, 2015).

In spite of the economic viability of jewellery production and its associated businesses both in Ghana and internationally, the jewellers who will produce to supply the market are scarce due to unavailability of expanded Jewellery Education facilities in Ghana. The study therefore sought to evaluate the Jewellery subject in Senior High Schools in Ghana to ascertain the career opportunities in jewellery for Ghanaian. To this end, the researchers asked the questions: what are the processes involved in skills acquisition in SHS Jewellery subject and what are the challenges that hinders effective skills acquisition in SHS Jewellery subject in Ghana?

\section{Literature review}

\subsection{Vocationalization of second cycle education in Ghana}

There have been varying approaches by countries when it comes to vocationalization of the mainstream education curriculum. Among them is a system where the components of a programme's (Visual Art, Home Economics, etc.) curriculum are made up of a core and varied clusters of elective subjects that include vocational and technical subjects. Claxton et al. (2010) postulate that the "provision of materials, activities and teaching that is designed to prepare people to function, at a specified level, in specific roles in the context of (usually) paid employment" is what is termed as Vocational education. They further indicated that vocational education has three main categories which include:

1. Knowing and applying physical materials in working.

2. Acquiring skills in human relations as well as team work.

3. Using symbolism (such as: words, numbers and images) as a tool for learning about working. 
In Ghana, the inclusion of vocational education into the educational system commenced in the mid-1960s. However, it was in 1987 when comprehensive policy was instituted to make 'vocational education' an essential component of the Ghana's education system from the basic to the secondary levels (Akyeapong, 2002). The policy was among other things to expose pupils and students at the basic and secondary levels of education to a diversified "practical activities in the vocational field in order to make them familiar with, and stimulate their interest in, vocational subjects and so give them equal opportunity to choose their future careers in either the technical or general field" (Baiden, 1996).

On the contrary, critics of the policy of vocationalization think that the policy is too ambitious and its implementation has been done hastily. Among the issues raised by some critics of the policy is that the 1987 reform was implemented without recourse to the corresponding resources that are required for implementation (Akyeampong, 2002).

\subsection{Jewellery under visual arts in senior high school education in Ghana}

An enquiry into the educational system in Ghana by the researchers revealed that jewellery is taught and learnt at the second Cycle (SHS) and tertiary (college/university) levels, of which both are terminal points. At the Senior High School jewellery is taught as a subject in the Visual Art programme, but that of tertiary level is offered as bachelor and master degree programmes (Baidoo, 2018). The study of jewellery was not offered at the SHS until 1990. Studying of jewellery at the SHS came by after the Evans-Anfom 1987 Education Reform's report made the Curriculum Research and Development Division (CRDD) of the Ministry of Education introduce Jewellery as an elective subject in then Senior Secondary School (SSS) which is now Senior High School (SHS) Visual Art programme (J. M. Annang, personal communication, June 15, 2017). The rationale behind the introduction of jewellery subject in the SSS programmes was to train people who will preserve the rich cultural heritage of Ghana through the production of authentic Ghanaian jewellery. Aside that the introduction of the jewellery subject is to train students as jewellers with the necessary knowledge and skills to fill the manpower gap in the jewellery making sector. Furthermore, it was to afford opportunities to the youth to build careers in jewellery for their future as well as embark on the value addition and transformation of the abundance mineral resources in Ghana (such as gold, silver and diamond), to maximise the benefits to the country, other than export them in its raw form to the developed countries.

Comparatively, the jewellery subject was introduced toward facilitating the production and export of well-designed authentic traditional jewellery. In a way, the interest of the jewellery student will be built in the areas of critical thinking and problem solving not forgetting their aesthetic potentials (CRDD, 2010). The overall benefit that is expected to be accrued is targeted at improvement of quality of life of the students and their dependants as well as the society as a whole which will end up in contributing to the economic growth of the country. The jewellery curriculum is designed in a manner that allows a student pursuing jewellery to learn it for 3 years after which the student goes to write the West African Secondary School Certificate Examinations (WASSCE) to qualify to enter higher education or the job market, specifically jewellery industry.

\subsection{Training to become professional jeweller in Ghana}

As stated in the introduction, there are two main systems that train experts in jewellery making, which are schoolbased and apprenticeship systems. The School-Based training has a structured system known as curriculum that guides the processes for teaching and learning of jewellery making. (Baidoo et al., 2019). This conforms with the view of Callahan (2000) which states that the heart of any educational activity is exclusively based on the curriculum and instruction that accompany it. Also, it reflects the view of Mouzakitisa (2010) who states that curriculum in vocational programme (such as Jewellery) is the passageway that leads to the training of professional knowledge and skills that enable the drift from concept (theory) to hands-on. With the availability of the curriculum at the disposal of the learner, he/she can predict what he/she is going to learn. A careful observation of the curriculum of the school-based jewellery training system (tertiary level) reveals that it contains contents that have the ability to generate all the six outcomes that are expected of every vocational education programme as proposed by Lucas et al. (2012), namely, routine expertise, resourcefulness, functional literacy, craftsmanship, business-like attitudes and wider skills. In like manner, instruction and learning in the Jewellery apprenticeship programme also have expected outcomes which are similar to that of vocational education with the exception of functional literacy. 
Unlike the school-based training, teaching and learning in the apprenticeship in the Jewellery system in Ghana is not based on any curriculum rather the knowledge and skills that the Master Jeweller teaches the apprentice is driven by the nature of jewellery orders he/she received from customers. Baidoo (2018) postulates that irrespective of the system that one chooses to learn to become expert in jewellery making in Ghana the person should go through the following contents.

- Health and safety practises in jewellery making

- How to handle tools and equipment

- Workshop management

- Melting

- Milling (sheet and wire)

- Drawing

- Piercing

- Forming

- Finishing

- Casting (cuttlefish and cement)

- Stone setting

- The duration for the programme is for 4 years.

\section{Methodology}

The researchers adopt elements of both qualitative and quantitative research approaches to address the issues that informed the study. According to Johnson et al. (2007) when a researcher or team of researchers combine elements of qualitative and quantitative research approaches (for example, use of qualitative and quantitative viewpoints, data collection, analysis, inference techniques) for the broad purposes of understanding and corroborating the breadth and depth of the issues under studies, such approach is said to be Mixed Methods Research. It must be stated here that the qualitative elements in this study were more than that of the quantitative element. The descriptive research was used to describe the actual processes involved in teaching and learning as well as the challenges that are confronting the studying of SHS jewellery subject in Ghana. Document analysis on the other hand, was adopted to examine the content of the SHS jewellery subject syllabus.

Population for the study were made up of Visual Art teachers and students at two senior high schools in Accra. The target population on the other hand were made up of teachers and students who teach and learn jewellery elective respectively (from SHS 1-3). In order to achieve the objectives of the research without necessarily involving the entire jewellery students, the researchers selected a sample size of 223 from the accessible population through stratified and purposive sampling techniques (Kelley et al., 2003). Both structured and unstructured interviews in the form of face-toface contact and contact over the telephone were used. The use of interviews was based on the fact that the number of teachers who teach jewellery in all the schools happens to be only 4. Again, voice recording and note taking were used to capture some of the interviews (Merriam, 1998).

Averagely, interviews with the jewellery teachers lasted for one hour thirty minutes.

The quantitative data were collected through questionnaire. The researchers used Thematic Analysis plan to generate findings from the qualitative data, while a Statistical Package for the Social Sciences (SPSS) was used to organise and analyse the quantitative data. Among the qualitative data that was analysed by the researchers is the Ghana Education Service's 2008 and 2010 Jewellery syllabus for SHS. The researchers used concurrent analysis (CA) to analyse the qualitative and quantitative data collected. Here the qualitative and quantitative phases of the study were conducted at the same time and the results of the two were analysed and interpreted concurrently to determine whether the data collected through the two research approaches were in agreement with each other. The researchers limited themselves to the use of descriptive statistics rather than inferential statistics. The use of basic features of data in a study to describe the general tendencies such as percentage, mean, median and mode in the data descriptive statistics here refers to (Trochim, 2006). Presentation and discussion of findings were descriptively presented with tables, figures, diagrams and plates to support. 


\section{Findings}

\subsection{Processes involved in skills acquisition in senior high school jewellery subject in Ghana}

The findings on research question one is based on structure of the SHS jewellery syllabus (subject), demographic features of the respondents and processes used in teaching and learning of jewellery.

\subsubsection{Structure of the SHS jewellery syllabus (subject)}

The jewellery subject as illustrated in Table 1 is structured to take three academic years to complete. The syllabus is organised in sections with first year having six sections; the second year have six sections and the third year have three sections. Within a section are a number of topics that are referred to as units which are required to be taught within a specified time.

Table 1. Organisation and structure of the SHS jewellery syllabus (CRDD, 2008; CRDD, 2010)

\begin{tabular}{|c|c|c|}
\hline SHS 1 & SHS 2 & SHS 3 \\
\hline Section 1: Jewellery as a vocation & $\begin{array}{l}\text { Section 1: Professional ethics and } \\
\text { entrpreneurial practices-1 }\end{array}$ & $\begin{array}{c}\text { Section 1: Advanced jewellery production } \\
\text { techniques }\end{array}$ \\
\hline $\begin{array}{c}\text { Unit 1: Meaning of jewellery } \\
\text { Unit 2: Types and uses of jewellery } \\
\text { Unit 3: Importance of jewellery as a field of study } \\
\text { and vocation } \\
\text { Unit 4: The Jeweller and ethics of the profession }\end{array}$ & $\begin{array}{c}\text { Unit 1: Artist's portfolio } \\
\text { Unit 2: Business plan } \\
\text { Unit 3: Branding and packaging } \\
\text { Unit 4: Artist's statement, brochure and } \\
\text { business card } \\
\text { Unit 5: Exhibition }\end{array}$ & $\begin{array}{c}\text { Unit } 1: \text { *Jewellery production and finishing } \\
\text { using variety of techniques and materials } \\
\text { Unit 2: *Application of jewellery finishing skills } \\
\text { Unit 3: Care and storage of jewellery items } \\
\text { Unit 4: Project report writing }\end{array}$ \\
\hline Section 2: Historical background of jewellery & Section 2: History of jewellery in ghana & Section 2: Exhibition and entrepreneurship \\
\hline $\begin{array}{c}\text { Unit 1: Origin of jewellery } \\
\text { Unit 2: Usage of jewellery by early cultures } \\
\text { Unit 3: Symbolism in jewellery }\end{array}$ & $\begin{array}{c}\text { Unit 1: History and development of } \\
\text { jewellery in Ghana } \\
\text { Unit 2: Jewellery producing and } \\
\text { marketing centres } \\
\text { Unit 3: Contribution of jewellery towards } \\
\text { development of Ghana } \\
\text { Unit 4: Glass, clay and stone bead production }\end{array}$ & Unit 1: Entrepreneurial skills in practise \\
\hline Section 3: Tools, equipment and materials & Section 3: The jewellery workshop & Section 3: Exhibition and entrepreneurship \\
\hline $\begin{array}{l}\text { Unit 1: Types of tools and equipment } \\
\text { Unit 2: *Preparation of tools } \\
\text { Unit 3: Sources of materials } \\
\text { Unit 4: Maintenance, care and storage, } \\
\text { health and safety } \\
\end{array}$ & $\begin{array}{l}\text { Unit 1: Tools and equipment } \\
\text { Unit 2: Organisation of the workshop } \\
\text { Unit 3: Packaging and handling }\end{array}$ & $\begin{array}{l}\text { Unit 1: Building portfolio of works } \\
\text { Unit 2: Exhibitions } \\
\text { Unit 3: Entrepreneurial skills in practise } \\
\text { Unit 4: Packaging and handling }\end{array}$ \\
\hline Section 4: Design and technology & Section 4: Basic metalwork for jewellery & \\
\hline $\begin{array}{l}\text { Unit 1: Meaning of design } \\
\text { Unit 2: Perceiving objects with the senses } \\
\text { Unit 3: Free-hand designing and drawing } \\
\text { Unit 4: The design and technology process } \\
\text { Unit 5: Computer aided designing }\end{array}$ & $\begin{array}{l}\text { Unit } 1: * \text { Metal preparation } \\
\text { Unit 2: * Metal jewellery fabrication processes } \\
\text { Unit } 3: * \text { Alloy calculation }\end{array}$ & \\
\hline $\begin{array}{c}\text { Section 5: Design and production of } \\
\text { jewellery items }\end{array}$ & $\begin{array}{l}\text { Section 5: Metal jewellery design } \\
\text { and production }\end{array}$ & \\
\hline $\begin{array}{l}\text { Unit 1: Preliminary designs and idea development } \\
\text { Unit 2: } * \text { Translating preliminary designs } \\
\text { into final products } \\
\text { Unit 3: Combining beads with accessories }\end{array}$ & $\begin{array}{l}\text { Unit 1: * Metal casting processes } \\
\text { Unit 2: Gemstones and usage }\end{array}$ & \\
\hline Section 6: Jewellery finishing processes & Section 6: jewellery for sustainable development & \\
\hline $\begin{array}{l}\text { Unit 1: The need for finishing } \\
\text { Unit 2: * Processes and techniques for finishing } \\
\text { Unit 3: Appreciation and Criticism }\end{array}$ & $\begin{array}{c}\text { Unit 1: The significance of sustainable } \\
\text { development to society and } \\
\text { the jewellery industry }\end{array}$ & \\
\hline
\end{tabular}

*: the jewellery practical topics. 


\subsubsection{Demographic features of the respondents (jewellery teachers and students)}

The demographic information of the jewellery teachers as indicated in Figure 1, was made up of four teachers who were all females. Three of them are holders of Bachelor Degrees in Education, Art Education, Jewellery and Textiles, while the fourth teacher holds Master Degree in Education Administration. All of them obtained their respective academic qualifications from University of Education, Winneba (UEW) in Ghana. Two of the teachers claimed that they Jewellery Apprenticeship for a period of one month and three years respectively to acquire additional skills in jewellery making in order to be effective in teaching the jewellery subject. None of the four teachers, has ever practise as a jeweller, because they do not have much experience in jewellery making. This was made clear when teacher one (T1) was asked how did she get her training as a jeweller. In her response, she said "It is out of interest, I learnt on my own and I had some training from Diamond House [Precious Mineral Marketing Company in Accra] ... in a short period for about two weeks but for the rest sometime I read I experiment".

Gender: On the other hand, the gender components of the students were made up of 174 males and 45 females with 1 person refusing to identify the gender, bringing the total students' respondents to 220 .

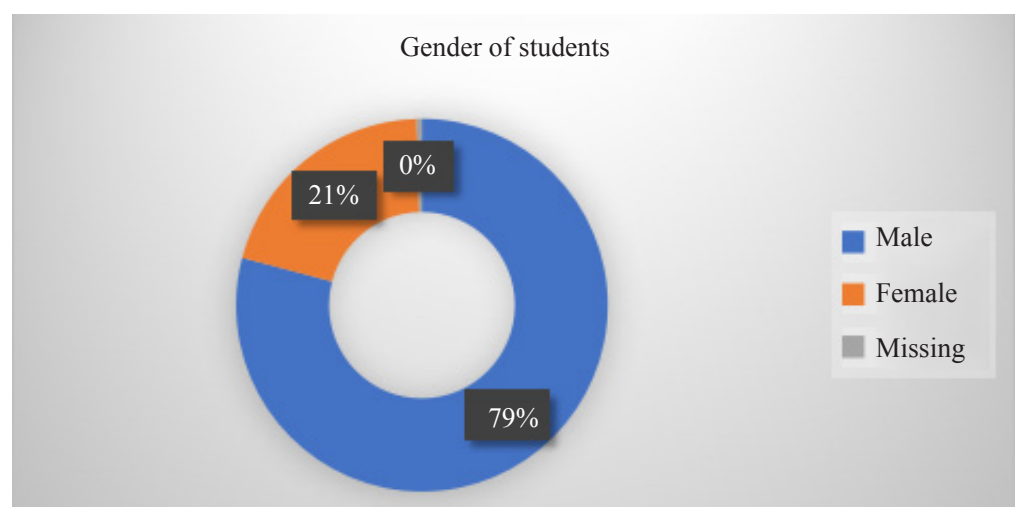

Figure 1. Gender distribution of students (Fieldwork)

Age: Furthermore, the age distribution (as shown in Figure 2) was found to be 1.8\% were below the sixteen (16) years old, while majority of them (85.5\%) were from sixteen to eighteen (18) years old. Meanwhile $10.9 \%$ had ages from nineteen to twenty-two (19-22) years old, with less than $2 \%$ having ages which were more than twenty-one (21) years old.

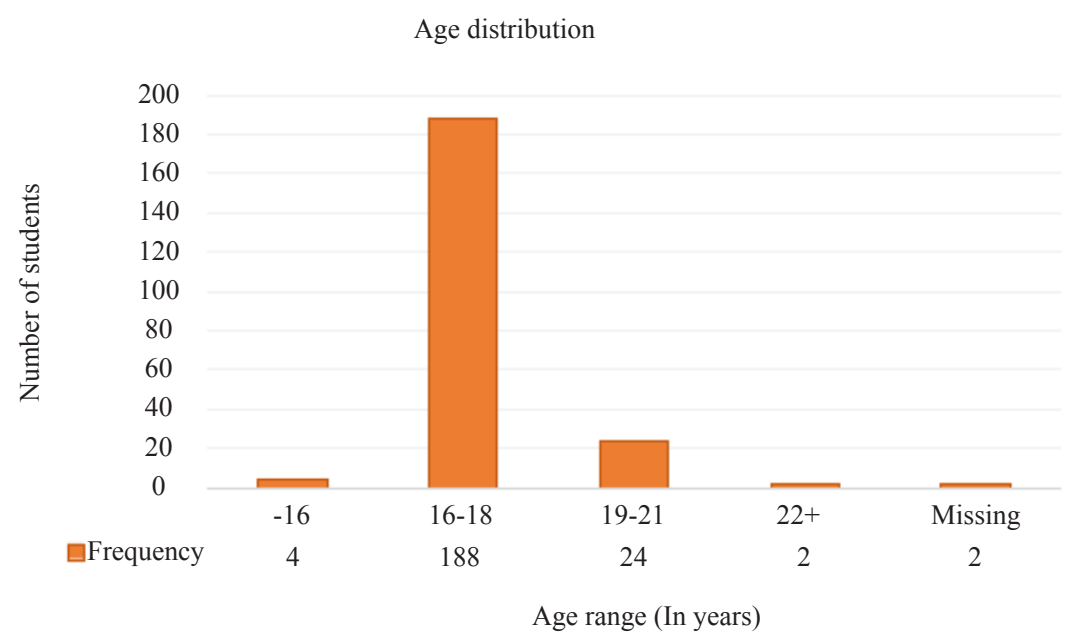

Figure 2. The distribution of the respondents' age (Fieldwork) 
Class distribution: The classes of the students (subjects) were found to be $31(14.1 \%)$ in SHS One, 111 (50.5\%) in SHS Two and $78(35.5 \%)$ in SHS Three.

Motivation: The factors (Figure 3) that influenced the respondents to study jewellery were found to be, 36.4\% indicated that they were influenced by the fact that the jewellery subject provides a good foundation for further education. On the hand, $22.7 \%$ stated that the occupations that are related to the jewellery subject appealed to them hence, their choice of the subject. In another vain $11.8 \%$ said they were impressed upon by their parents to pursue jewellery, while 6.4\% alleged that they were studying the jewellery subject as a result of the Computer Placement System. Other respondents (5.5\%) said their previous examination grades prevented them from enrolling on more preferable programme, consequently they were left with no option than to choose to study jewellery. Aside these reasons, $1.4 \%$ claimed that they choose to learn jewellery because their friends had chosen to undertake the same subject. Meanwhile, $10.9 \%$ of the students specified that their former teachers encouraged them to enrol on the jewellery subject.

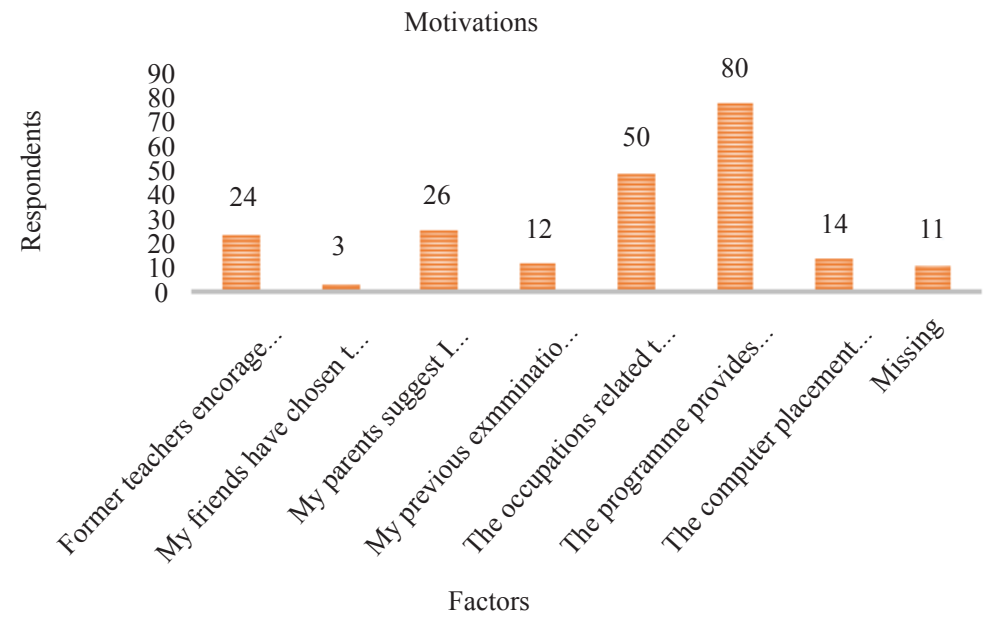

Figure 3. Factors that influence students' pursuit of jewellery (Fieldwork)

Another resources which play a vital role in teaching and learning of practical is materials for jewellery making. All the four teachers indicated that it is the responsibility of the students to purchase the materials for practical lessons. This was collaborated by majority of the students as the results in the Figure 4 shows. One of the teachers (Teacher one) claimed that her school used to provide the needed materials to students to work, but that has since stopped.

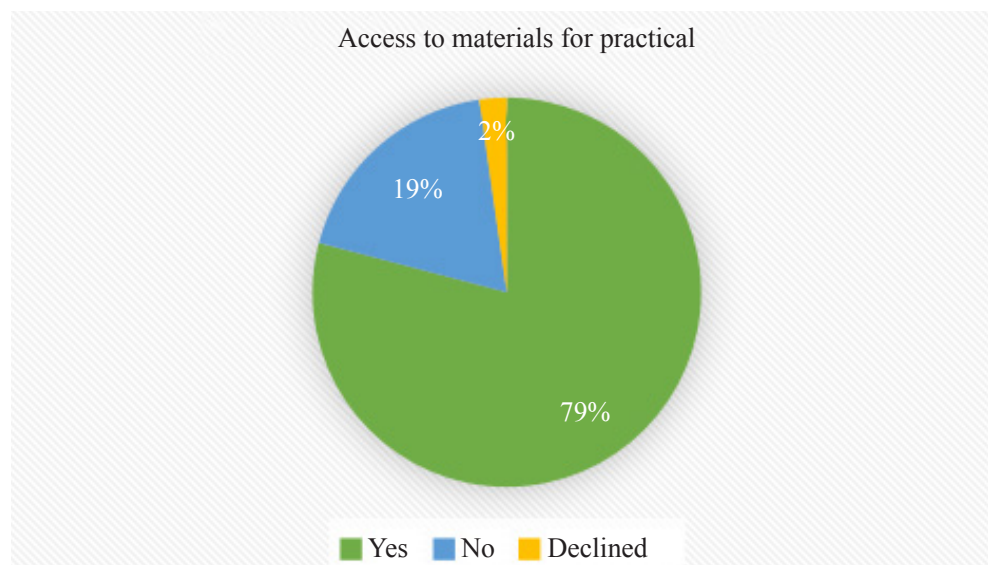

Figure 4. Availability of materials for jewellery practical activities (Fieldwork) 


\subsubsection{Processes of teaching and learning of jewellery practical activities}

The rationale for including jewellery subjects in Visual Art curriculum is to train the students to acquire the practical experiences on how to produce and manage jewellery business. In that vein, the researchers sought for the rate at which practical activities are organized for the students in a term. The information obtained from the teachers suggests that jewellery practical activities are organised for students depending on the topics in the jewellery syllabus. According to three of the teachers, if there are practical activities attached to a particular topic, when they are treating such topic, they do so hand-in-hand with the theory. An observation by the researchers on the noticeboard of the schools revealed that jewellery subject has been allocated 5 periods ( 40 minutes for a period) per week on their timetable for each class. The Form One class, use three periods for topics that are theory and the other two periods for practical exercises.

According to the four teachers, the structure of the jewellery syllabus jewellery syllabus is such that the early stage contains more theory content than practical. This changes as the student progress to the second and third year. The teachers stated that on the average produce between three and five jewellery items in a term. As it can be seen in Figure 5, majority $(59 \%)$ of the students also collaborate what their teachers said about the number of jewellery items they produce in a term.

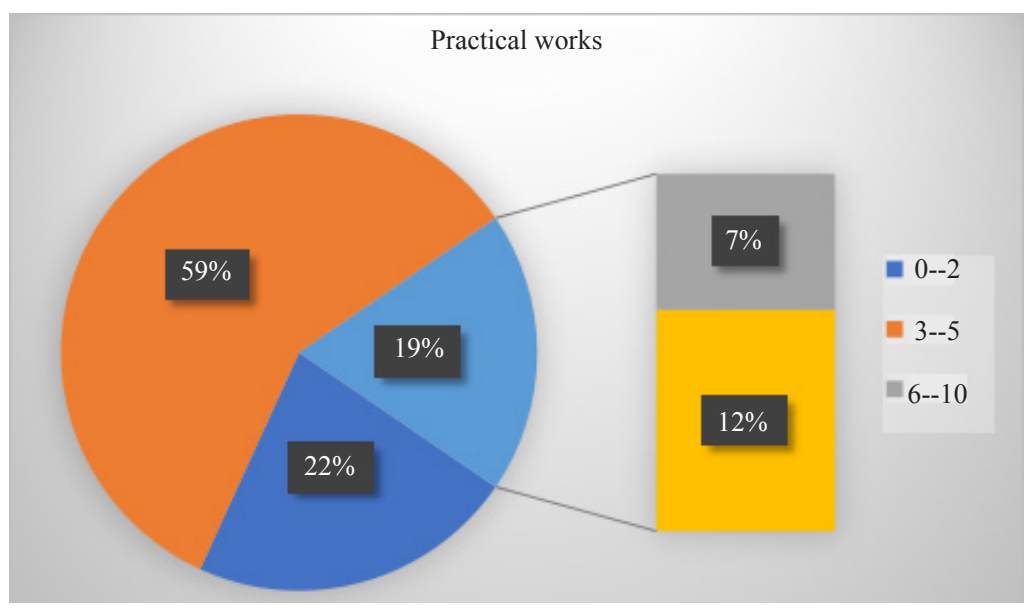

Figure 5. Number of jewellery related items produced in a term (Fieldwork)

Further probe into the practical activities shown that $202(91.8 \%)$ of the students always take part in practical exercises that their teachers organise, while $12(5.5 \%)$ do not participate in. An investigation by the researchers into why some of the students do not usually partake the practical lessons revealed responses such as "I don't enjoy the jewellery practical, because I made my mind that I would be a science student but the science class was full". This response is similar to that of another respondent who said "I don't actively participate because I don't like the jewellery subject at all".

Recounting on the first jewellery item that they produced, the sampled students indicated that the first practical activity that they undertook under the jewellery subject is "Paper Bead Jewellery". The study revealed that the process that the teachers use to teach the practical as; the teachers first take the students through the theoretical components of the topics by first teaching the students the names of the tools, equipment, machineries and materials that they require for the particular practical work, after that the students are made to learn how to draw some of the tools and equipment. The teacher then proceeds to guide the students to design their respective project on paper which has to be approved by the teacher before the execution of the actual work. When it comes to the practical, the teacher will do a demonstration before they allow the students to do theirs. For instance, in one of the schools if a project like bone jewellery is to be undertaken, the school has a workshop assistant who cuts the bones into pieces and shares them to the students to reshape with the grinding machine and files to obtain their preferred design. After that the students apply the various finishing processes which include sandpapering, threading and polishing.

With the limited facilities at their disposal as against large students' numbers, the practical is normally done in 
groups and batches. For instance, Teacher two (2) indicated that if the students are to learn how to draw wire, one group will be preparing their metal, another will be milling whiles other groups will be drawing or annealing. In all of these activities' timelines are given to the students within which they are to finish, because failure to finish within the specified time frame will attract less mark which sometimes can lead to other punishment.

The main pivot that imparting of knowledge and skills of jewellery making surrounds is the expertise of the jewellery teacher and how they applies it to teaching. Students being the receivers of what the teachers teach, the researchers through Likert scale asked the students to assess the performances of their teacher as far as teaching jewellery is concerned as against the knowledge and skills they received. The outcome as indicated in Figure 6 suggests that majority $(52.7 \%)$ of the respondents said their jewellery teacher performs excellently and $30.6 \%$ graded their teacher Very Good, while $13.6 \%$ placed their jewellery teacher's performance at Good. Notwithstanding, $0.9 \%$ were of the view that their jewellery teacher performs poorly even some $0.9 \%$ of the respondents went to the extent of downgrading their teacher as very poor. There were $1.9 \%$ respondents who could not perform the task of assessing their jewellery teacher.

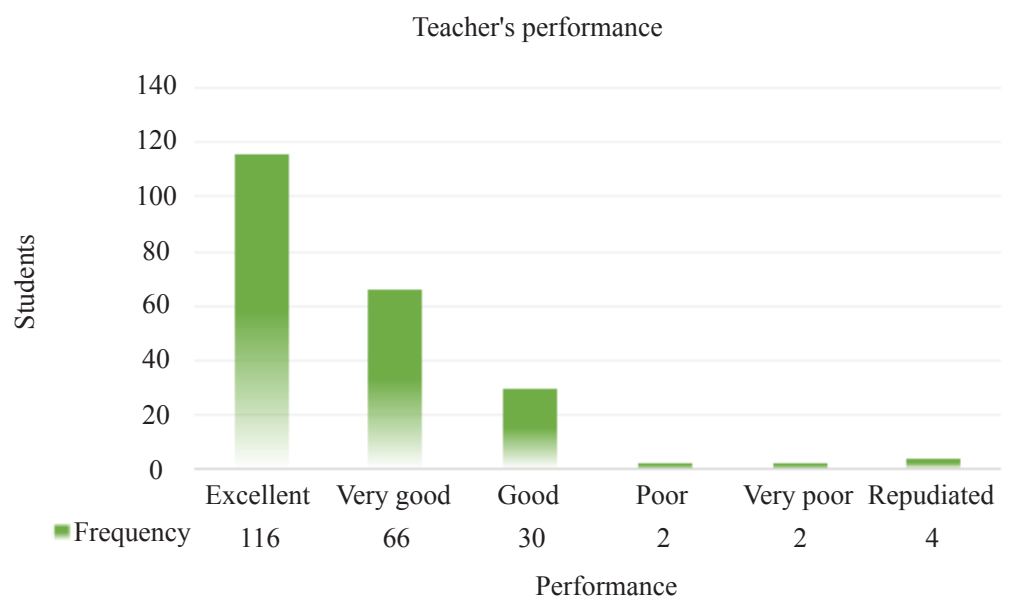

Figure 6. Respondents assessment of their jewellery teacher (Fieldwork)

\subsection{Challenges hindering effective skills acquisition in senior high school jewellery subject in Ghana}

Jewellery at the Senior High School just like any other elective subjects under the Visual Art programme is faced with a lot of challenges that disturb its effective teaching and learning. The foremost as indicated by the jewellery teachers included lack of funding from the government. Narrating her experience as someone who has been teaching jewellery for over two decades, Teacher two (1) opined that "the jewellery subject used to be financed with a levy of Gh $\varnothing 20.00$ per student every term in addition to some monies which were given by government to pay for expenses associated to practical lessons". She explained that when these monies are disbursed to the schools the headmistress released them to the Visual Art Department to buy the items that they needed for jewellery practical. This helped them to teach the students a lot of practical activities. However, she said:

Unfortunately, the government has since stopped releasing these monies for the past six years. The intriguing part is that the government not only stopped the funding for practical lessons, but also gave directive that no students should be levied outside the GES approved fees.

Meanwhile, the students refuse to bring their materials for practical. She claimed that since her school started offering jewellery for over 20 years, the government have done little to promote the jewellery subject, to the extent that the only jewellery workshop that the school has was built with internally generated funds from her school. In supporting these assertions, Teacher two (2) said:

I have been in this school for five years but have never gotten any wind of government's finance for teaching and learning of jewellery practical. So, the school has to levy the students to take care of all the practical 
activities that are associated with the subject, despite the fact that it is contrary to the GES directives.

The story was not different at the schools of Teacher three (3) and Teacher four (4).

On the part of the students they stated these as their challenges:

i. Inadequate time for practical work

ii. Lack of materials

iii. Insufficient jewellery teachers

iv. Scarcity of facilities and absence of interest by the students

v. Lack of interest by the students

As a result of these constrains, they were unable to do a lot of practicals that put them in the position to become professional jewellers after their schooling.

The study also reveals that the time allocated to jewellery on the timetable for both theory and practical is insufficient. This was based on the responses from the students where $70.2 \%$ indicated that the allotted time for jewellery is not sufficient, but $26.3 \%$ felt the time was enough while $3.5 \%$ refused to give any response. Articulating their views on the time allocated to jewellery, the four teachers alluded that there were certain jewellery items works that required longer time to produce. So, if they are teaching how to do such work and it run into the time of another subjects, it distracts the learning process, because leaving such works in midstream to attend to another class will render the work damaged. Citing an example, Teacher one (1) said:

Assuming the topic for the day is etching, and the metal is immersed in the etching solution (acid) and the period for the class elapses, the students may be required to move to the next class which means they have to either stop the process or leave the work in the solution and go. Meanwhile if the metal stays in the solution for a very long time, the work will be over etched and thereby spoiled. So, to avoid losing their work, the students sometime have to skip the next class to go through the processes to see the end result of their works.

Lack of jewellery teachers was also identified as a challenge by the students. According to some of them their school has only one jewellery teacher handling SHS1, 2 and 3 with student's population of 300 and an average class size of 100. In expressing his frustrations, one of the students said that "there is only one jewellery teacher in my school and if she is not around it makes learning difficult". This concern was share with Teacher three (3) who happens to be the only jewellery teacher in her school. She indicated that the total number of students that pursue jewellery was about 170 for SHS 2 and 3 excluding the first years that were yet to report to the school after they had been admitted. Meanwhile, her school does not have any jewellery studio, let alone other facilities for teaching and learning of jewellery. Yet she was being expected to train these students to become jewellers after three years of studies. How "possible would that be?" She quizzed.

The other challenge that the respondents identified was jewellery books. In every academic endeavour, one important resource that holds teaching and learning enterprise together is book. In view of this, the researcher inquires from the respondents (both teachers and students) if the Ghana Education Service has any approved book(s) for SHS Jewellery subject. The result was that the GES does not have any textbook for teaching and learning of jewellery so the teachers have to resort to the use of the jewellery syllabus. Confirming this from the study, a hopping 158 (71.8\%) of the jewellery students indicated that they do not have access to any jewellery book apart from the notes that their teacher gives them. Only $57(25.9 \%)$ respondents said they have some jewellery books even that the book that majority of them mentioned is a book on jewellery questions and answers from past West African Senior School Certificate Examination (WASSCE), 5 (2.3\%) were unable to give any response. Weight was placed on this view when one of the teachers (Teacher two) in an interview said "normally I use the syllabus, the research, the internet, and the notes from school. Then we are having one, it actually has no name, it is an old book that the other teacher was using" (personal communication, Date). The responses from the other 2 teachers were not far from what majority of the students indicated.

Another challenge that was enumerated by the teacher respondents is the calibre of students that are enrolled on the Visual Art programme who sometimes end up in pursuing jewellery. The teachers claimed that the authorities of education normally bring students who underperformed academically in their Basic Education Certificate Examination to the Senior High Schools, rather than sending them to the vocational institutions. The teachers were of the view that if such students are to go to vocational schools, then they would have become professionals in what they do but when they are brought to the mainstream education that is academically oriented, then they would be assessed on both theory 
and practical instead of only practical-based works. It emerged also from the study that some of the jewellery students do not have any idea about the subject so they impress on their parents to change their programme a few days when they start classes.

Two of the methods specified in the jewellery syllabus for efficient teaching and learning of the subject are attachments (internship) and institutional visit (Field Trips). However, both teachers and students in the schools that were used in the study were not exposed to these teaching and learning methods. For instance, $115(52.3 \%)$ stated that they had not gone on any attachment, but 90 (40.9\%) indicated that they had some attachment. Their responses to the issue of Field Trips were similar to that of attachment. This was shown in the answers that was given to the question, have you ever been taken to a place (field-trip) where they do jewellery related activities outside your school? As revealed in Figure 7, majority indicated that they had not embarked on any field-trip.

Field trip experience of students

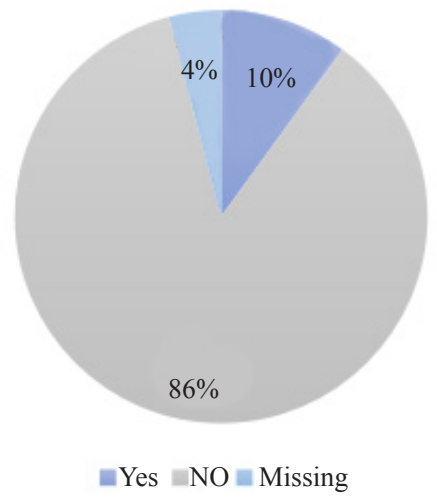

Figure 7. The respondents' experiences on field trip (Fieldwork)

With the stated challenges that are hampering effective teaching and learning of jewellery in the schools, the researcher gave the respondents opportunity to suggest possible remedies to mitigate the challenges. Their responses were centred on four themes. The first among them (not in any order of importance) is that more teachers should be made available for the jewellery subject as it will improve the contacts hours students get with their teacher. The second remedy professed by some respondents is field trip and attachments. According to the student respondents, all the things they are learning about jewellery are limited to what they are taught in the school. For them to gain more insight into the field of jewellery, they should be sent to excursions and attachments to jewellery companies and shops so that they will build more ideas, skills and techniques to improve on their practical works. This in a way will prepare them for the jewellery industry when they complete the SHS. The next proposed remedy is improvement of the facilities and supply of materials for teaching and learning. One of the respondents said authorities should endeavour to provide the schools with the state-of-the-art tools and equipment as well as materials for their training. It is only when the necessary facilities and resources are made available to the school that is when their teachers will be able to teach them to become good jewellers after school. Adding his voice, one of the respondents said, "I will be able to improve in my jewellery studies if only the workshop is equipped with adequate facilities and we are provided with textbooks".

The first among them (not in any order of importance) is that more teachers should be made available for the jewellery subject as it will improve the contacts hours students get with their teacher.

The second remedy professed by some respondents is Field Trip and Attachments. According to the student respondents all the things they are learning about jewellery are limited to what they are taught in the school. For them to gain more insight into the field of jewellery, they should be sent to excursions and attachments to jewellery companies and shops so that they will build more ideas, skills and techniques to improve on their practical works. This in a way will prepare them for the jewellery industry when they complete the SHS.

The next proposed remedy is improvement of the facilities and supply of materials for teaching and learning. One 
of the respondents said authorities should endeavour to provide the schools with the state-of-the-art tools and equipment as well as materials for their training. It is only when the necessary facilities and resources are made available to the school that is when their teachers will be able to teach them to become good jewellers after school. Adding his voice one of the respondents said, "I will be able to improve in my jewellery studies if only the workshop is equipped with adequate facilities and we are provided with textbooks". Majority of the respondents (50.9\%) subscribed to this remedy.

Another remedy given was increment of the number of practical works that they normally do for which majority pegged at 3 to 5 works in a term.

The view of the student buttresses the finding that GES does not have approved jewellery textbook for teaching and learning jewellery so the teachers as it was espoused by 158 out of 220 of the student respondents concur with the responses of all the three teachers who even added that they resort to the use of the jewellery syllabus to teach. This is in contradiction to Adedeji and Owoeye, (2002) who state that the contributing factor that propels effective teaching and learning to achieve a high academic standard is based on availability of appropriate resources (such as laboratories, libraries, instructional materials and art studios). What Adedeji and Owoeye failed to add is that the attractive facility has to go with the right Teacher Student Ratio (TSR). Because for skill-based subject like jewellery having only one teacher for a class of about 100 students as it is the case of all the schools that were used for the study, it will be extremely difficult for the teacher to reach all students.

Majority of the respondents $(50.9 \%)$ subscribed to this remedy. Another remedy given was increment of the number of practical works that they normally do for which majority pegged at 3 to 5 works in a term.

Lastly, the researchers sought for the reactions of the subject when they are giving another chances to choose a subject to study under Visual Art programme, in such situation what will it be jewellery?

Diverse responses emerged as it is shown in Figure 8. Here 6 (7.3\%) declined any response; $27(12.3 \%)$ stated that they will definitely not pursue jewellery again; $28(12.7 \%)$ indicated, it is most likely that they will select the same subject; but 64 (29.1\%) opined that they may will consider it; $81(36.8 \%)$ said they will definitely choose jewellery; 4 $(1.8 \%)$ they will rather not choose jewellery. This implies that majority of the students have keen interest in jewellery, for that matter there is the need to provide the school with the necessary facilities.

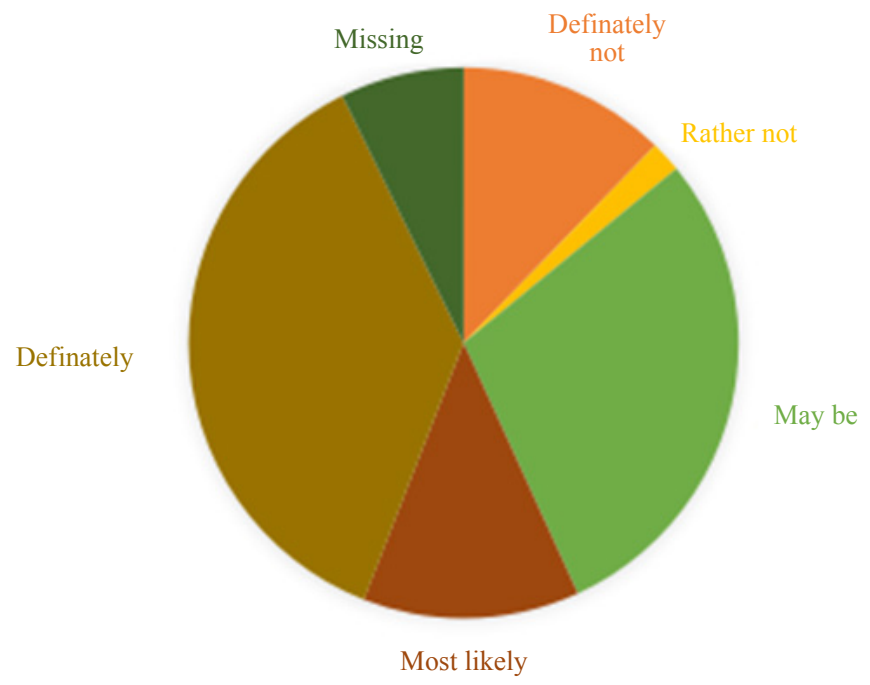

Figure 8. Respondents' interest in the jewellery subject (Fieldwork)

\section{Discussion of findings}

\subsection{Structure of the SHS jewellery syllabus}

The jewellery subject was introduced into the curriculum of SHS Visual Art programme to impact knowledge and 
skills of jewellery to student for them to preserve the rich cultural heritage of Ghana. This is expected to be done by them through the production of authentic Ghanaian jewellery which in effect will promote activities that will enable Ghana to launch a vibrant jewellery tradition within the country after their training. The reality, as far as teaching and learning of jewellery at the SHS level is concerned, does not point to this direction.

A careful analysis of the contents of the syllabus from SHS 1 to 3 shows that there are more jewellery theory topics than that of practical. For instance, out of 22 units under the 6 Sections of the SHS1, only two (Section 5-Unit 2: Translating preliminary designs into final products: Section 6-Unit 2: Processes and techniques for finishing) can be said to be jewellery making practical oriented. The situation in SHS 2 is not different from that of SHS 1 . But they have a bit more jewellery practical topics, which is made up 4 practical topics out of 19 units, (Section 4-Unit 1: Metal preparation, Unit 2: Metal jewellery fabrication processes, Unit 3: Alloy calculation and Section 5-Unit 1: Metal casting processes.) Similarly, the SHS 3 has just two (Section 1-Unit 1: Jewellery production and finishing using variety of techniques and materials, and Unit 2: Application of jewellery finishing skills) out of nine topics being jewellery practical oriented topics.

\subsection{Demographic features of the respondents (jewellery teachers)}

Almost all of the teachers that were interviewed do not have the expertise or professional competency in the jewellery making, yet they have been entrusted to teach students to become jewellers. As the results shows, some of the jewellery teachers are teaching the subject because they have personal interest in the jewellery subject. One may not fault the teachers much if they are unable to teach the students a lot of jewellery as their educational background is not in jewellery but rather in general education and textile. Aside that the institution in which the teachers attained their training does not run full jewellery programme. This was more revealing in the finding that showed that the areas of specialisation for the teachers being Education Administration and Textiles from University of Education, Winneba.

The features of the students on the other hand show a fair representation was made in the study as the result shows that the views of SHS 1,2 and 3 were sought in order to understand the nature and processes involved in teaching and learning of jewellery as an elective subject of Visual Art. The ratio of male to female of the respondents is approximated to be 4:1. Even though jewellery is mostly used by females when it comes to its studying, males are dominated as the findings of the study show. The quest to stimulate and maintain the interest of the youth in creativity in transforming the Ghana's mineral resources is stated among the general objectives for the introduction of jewellery in the Visual Art programme. The ages of the students as the study found make the fit for achieving that objective, as majority of the students aged (85.5\%) are between sixteen and eighteen years old.

\subsection{Processes of teaching and learning of jewellery practical activities}

The pedagogy of the SHS jewellery was found to be the type where practical components of the subject are organised for students depending on the topics in the jewellery syllabus. This process of teaching and learning of jewellery practical is to build the students' competencies in jewellery making as Gibson (2011) explains that skills development becomes more effective when there is a constant practise of technical works, it refines what the students acquire on regular basis. If the finding on how teaching and learning is to be the case it means that the SHS1 does only 2 practical activities, that of SHS 2 will be 4, while SHS 3 will be 2. Because those are topics that contain jewellery practical activities, which are inadequate to qualify someone become a jeweller. At end of their studies, students will be knowledgeable in jewellery rather than have the skills to practise as jewellers.

More so, in a situation where the structure of the jewellery syllabus gives room for any material that can be worked on to produce jewellery to be used without limitations. Against this background the teachers are themselves not practising jewellers, getting the liberty to use materials such as stick, bamboo, canes, paper, bones shells and metal as the media for teaching and learning of making jewellery at the SHS level. This causes the teachers to teach the kind of jewellery with which they are familiar without giving recourse to the rationale for the introduction of the jewellery subject in the first place. Hence, students go through the subject but fail to practice as jewellers.

Notwithstanding the finding which revealed that before the students learn how to do a particular jewellery item, the teachers take the students through the theoretical components of the topics, followed by first teaching the names of tools, equipment, machineries and materials that they require for the particular practical work. After that the students are 
designed the object to be produced, before models and the final jewellery piece is produced conforms to the Maxims of vocational pedagogy.

\subsection{Challenges confronting teaching and learning of the jewellery subject}

The quest to stimulate and maintain the interest of the youth in creativity is stated among the general objectives for the introduction of jewellery as one of the elective subjects in the Visual Art programme. However, certain deficiencies in the education system have rendered the achievement of this objective by the nation impotent. Among the challenges as the study found is funding. According to GTZ (2006), funding system in any skill-based studies has a great role to play in achieving the quality, efficiency and impact of Technical and Vocational Education Training (TVET) (such as jewellery) system. This forms the basis for the schools policy of charging the students to buy materials for practical lessons. But the directives of authorities of education in Ghana to school heads not to levy students outside the GES approved fees has caused some students to feel reluctant to provide their materials for the practical, thereby making the teaching and learning of jewellery very difficult. A situation that accounts for the low level of practical exercises that they undertake. Also, the mode of organising materials from students to undertake practical activities in jewellery replicate and lend further support to a similar study done by Opoku-Asare et al. (2014) who stated that when it comes to materials for students to use in undertaking GKA practical the "... levying the students and using the monies to purchase the required items every term. In this case only students who pay are given the items they need for practical assignments for the term". The troubling part is that practical activities may have to delay if the teacher want to make sure that every student take part in the practical aspect of the jewellery subjects Braun, ect. Then he/she has to make sure that every student has paid his/her money before the materials are purchased.

The study result shows that the schools lacking jewellery teachers is a big challenge. This was shown in the number of students each teacher teaches. Because for one teacher to teach a class of about 100 students in skill-based subject like jewellery, falls out of the accepted Teacher Student Ratio. What is pertaining at the schools where jewellery is taught makes it difficult for the teacher to reach all students. With the limited facilities at their disposal as against large number of students, in such situation, the only option available to the teacher is the use of grouping so that every student can participate in the learning activities, in order to motivate them to learn (Child, 2004).

But looking at the nature of the jewellery subject being practically oriented subject (studio-based) group methods of teaching will not be enough for effective teaching and learning. Assuming the teacher is to go by TSR of 25 students to one teacher which is the stated ratio for the SHS in Ghana, it will mean that the class of 100 students, the teacher will have 4 groups of 25 members each. All of the groups are supposed to use the same 40 minutes that is allocated for a period, the teacher will be able to reach out to each group but cannot have direct contact with individual students.

The researchers are of the view that the jewellery teachers will find it difficult to monitor the behaviour of the students as well as maintain high learner attention rate. At best, the teachers will spend most of their time in teaching the whole class instead of offering attention to individual students. These situations present two negative outcomes, which include; the slow-paced students fall back and suffer whiles few active students will be able to accomplish the task when the teacher gives assignments to the groups. The second one is lazy students may take advantage of their large class size to outsmart their teachers by outsourcing their practical course work for marks. Morrow (2007) postulates that congestion in classroom prevents teachers from giving individual attention as well as making use of participatory learning and assessments.

The finding that shows that GES does not have approved jewellery textbook for teaching and learning jewellery as it was espoused by 158 out of 220 of the student respondents concur with the responses of all the three teacher who even added that they resort to the use of the jewellery syllabus to teach. This is in contradiction to Adedeji and Owoeye (2002), who state that the contributing factor that propel effective teaching and learning to achieve a high academic standard is based on availability of appropriate resources (such as laboratories, libraries, instructional materials and art studios). What Adedeji and Owoeye failed to add is that the attractive facility has to go with the right teacher student ratio (TSR). Because for skill-based subject like jewellery having only one teacher for a class of about 100 students as it is the case of all the schools that were used for the study, it will be extremely difficult for the teacher to reach all students.

Industrial attachment and field trips are to two important methods of learning, whereby students get a feeling of what they learn in school represents in real world of work is two of the proposed educational activities that support and strengthen the appreciation of concepts. On these two learning methods, Hurwitz and Day (2001) opine that field trips 
for art students help them to get first-hand experience of an original art work that has been made in high quality could be a reference point to enable the students understand the theories their teachers present to them in school. However, this is not the case of the jewellery students as the findings of the study show that the students had not gotten any experience on attachment and field trip. For students, to study a hand-on subject like jewellery is not able to get the chance to go on attachments or field trips put them in the disadvantage of the jewellery profession that they intend to join after school.

The outcome of the study that attests that authorities of education normally enrol students who underperformed academically in Basic Education Certificate Examination to the secondary schools who eventually end up in the Visual Art class. This suggest that the interest of the students is not considered before they are assigned to do the Visual Art including the jewellery. This is one of the underpinnings that cause some students not to give their best of efforts in learning the jewellery. As one student said that he does not partake in jewellery practical because he wanted to do Science but he was told the Science class was full therefore he has to study jewellery. He even went on to appeal to school authorities if they can give him his preferred course which is Science. This means that student's interest in a subject is vital to his or her involvement in undertaking practical activities of the subject.

The finding of the study shows that insufficient time allocated to jewellery on the school's timetable for both theory and practical exercises, is a contributing factor that prevent them from engaging on a lot of practical activities. The researchers agree fully with the students, because the cumulative time that is allocated to jewellery subject for the three years SHS programme is equivalent to a little below 13 days as it is shown in Table 2 . This time is definitely inadequate for training somebody to become a jewellery even if the person has all the resources and facilities at his or her disposal, how much more a school who virtually has nothing as far as the resource and facilities for teaching and learning jewellery is concerned.

Table 2. Breakdown of the time allocated to the jewellery subject within 3 years

\begin{tabular}{ccccccc}
\hline & Period 1 & Week $(5 \mathrm{p})$ & Month $(20 \mathrm{p})$ & Term $(60 \mathrm{p})$ & Year $(1800 \mathrm{p})$ & Completion $(450 \mathrm{p})$ \\
\hline Minutes & 40 & 200 & 800 & 2,400 & 7,200 & 18,000 \\
Hours & - & 3.3 & 13.3 & 40 & 120 & 300 \\
Days & - & - & 0.5 & 1.6 & 5 & 12.5 \\
\hline
\end{tabular}

\section{Conclusion}

The rationale for introducing the jewellery subject which is to train students with the necessary knowledge and skills to fill the gap of manpower in the jewellery making sector (CRDD, 2008). Secondly it was also to afford opportunities to the youth to build careers for their future as well as embark on value addition and transformation of the mineral resources such as, gold, silver and diamond, which are abundant in Ghana, for maximum benefits to the country as compared to exporting them in its raw form. From the findings of the study, the researchers conclude that: majority of the students who pursue SHS Jewellery are not able to practise as jewellers after they complete their studies. This can be attributed to the fact that the content of the jewellery subjects and its associated exercises do not correspond to what pertain on the Jewellery Industry as the literature in 2.3 of this paper shows. Coupled with the fact that the teachers who teach the jewellery are mostly not professional Jewellers, which therefore limit the kind of practical jewellery that they can teach the students.

Secondly, the content of jewellery syllabus is overloaded as compared to the time allocated to it. Similarly, the high student/teacher ratio has resulted in ineffective teaching and learning of jewellery at the school-based programme as against the backdrop that the schools lack the requisite resources for training jewellers.

There is the need for SHS jewellery teachers to change their mind-set through the process of re-engineering and retooling to embrace new development approaches in pedagogical skills in the jewellery subject. Although, the motivating factor for introducing jewellery was good, however, the rhetoric's of the government that she wants students to acquire skills in jewellery making does not support the reality on the ground because the government does not show much 
interest in funding vocational education in general let alone jewellery subject.

The Government of Ghana is being called upon to pay more attention to the jewellery subject because the subject has the potential to train students in the multibillion-dollar jewellery sector. This is based on the study of Dauriz et al., (2014) which state that "the jewellery industry seems poised for glittering future. Annual global sales of $€ 148$ billion are expected to grow at a healthy clip of 5 to 6 percent each year totalling $€ 250$ billion by 2020. Consumer appetite for jewellery, which was damped by the global recession, appears more vicious than ever". The researcher is of the opinion that if the state is really interested in training these students to become jewellers after their SHS, then the necessary logistics has to be provided for the training of the students to become experts in jewellery making.

\section{References}

Adedeji, S. O., \& Owoeye, J. S. (2002). Teacher quality and resource situation as determinants of students academic achievement in Ogun State Secondary Schools. Journal of Educational Management, 4, 36-45.

Adams, VA (2008). Skills Development in the Informal Sector of Sub-Saharan Africa. Washington, World Bank.

Akyeampong, A. K. (2002). Vocationalization of Secondary Education in Ghana: A Case Study. Washington, District of Columbia: World Bank.

Atchoarena, D., \& Delluc, A. (2001). Revisiting technical and vocational education in Sub-Saharan Africa: An update on trends, innovations and challenges. Paris: International Institute for Educational Planning. Washington: World Bank.

Baiden, F. A. (1996). Technical and vocational education in Ghana. In The Development of Technical and Vocational Education in Africa (pp. 81-122). Dakar, Senegal: UNESCO Regional Office.

Baidoo, M. K. (2018). Jewellery Education in Ghana: A comparative Analysis of School-Based and Apprenticeship Programmes. Ph.D. Thesis, KNUST.

Baidoo, M. K., Tachie-Menson, A., \& Arthur, N. A. P. (2019). Jewellery education in Ghana: A comparative analysis of school-based and apprenticeship programmes. Global Journal of Human-Science, 19(3), 23-31.

Braun, V., \& Clarke, V. (2006). Using thematic analysis in psychology. Qualitative Research in Psychology, 3(2), 77101.

Callahan, C. M. (2000). Evaluation of services to gifted students in Groose Point Public schools. Groose Point, MI University of Virgina.

Child, D. (2004). Psychology and the Teacher (7th ed.). Continuum Midas International Ltd.

Claxton, G., Lucas, B., \& Webster, R. (2010). Bodies of Knowledge: How the learning sciences could transform practical and vocational education. Edge/Centre for Real-World Learning.

CRDD (2008). Teaching Syllabus for Jewellery. Ministry of Education.

CRDD (2010). Teaching Syllabus for Jewellery. Ministry of Education.

Dauriz, L., Remy, N., \& Tochermann, T. (2014, February 1). A multifaceted future: The jewelry industry in 2020. https:// www.mckinsey.com/industries/retail/our-insights/a-multifaceted-future-the-jewelry-industry-in-2020.

Education Act (2008). The Seven Hundred and Seventy-Eighth Act of the Parliament of the Republic of Ghana (pp. 3). Ministry of Education.

Fening, P. A. (2015). Post-independence developmental trends of the Gold Jewellery Industry in Ghana: A case study of Asantes. PhD Thesis, Kwame Nkrumah University of Science and Technology, Kumasi, Ghana.

Fening, P. A., \& Asomaning, K. A. (2014). Towards a viable competitive gold jewellery industry in Ghan. CASS Journal of Art and Humanities, 3(1), 103-115.

Gibson, A. (2019, August 10). Stages of skill acquisition. http://www.prezi.com/hi3g_n1kkuwu/stages-of-acquisition.

Graves, K. (2009). Teachers as Course Developers. Cambridge University Press. DOI: https://doi.org/10.1017/ CBO9780511551178.

GTZ (2006). Implementation issues of diversified financing strategies for TVET. In Proceedings of the International symposium on Implementation issues of diversified financing strategies for TVET. Ethiopia: Addis Ababa.

Hurwitz, A., \& Day, M. (2001). Children and their Art: Methods for the Elementary School (7th ed.). Harcourt College.

Johnson, R. B., Onwuegbuzie, A. J., \& Turner, L. A. (2007). Toward a definition of mixed methods research. Journal of Mixed Methods Research, 2, 112-133.

Kelley, K., Clark, B., Brown, V., \& Sitzia, J. (2003). Good practice in the conduct and reporting of survey research. International Journal for Quality in Health Care, 15(3), 261-266.

Kotoku, W. (2009). Ghanaian Jewelry Industry: Its Problems and Solutions. PhD Thesis, Kwame Nkrumah University 
of Science and Technology, Ghana.

Lucas, B., Spencer, E., \& Claxton, G. (2012). How to teach Vocational Education. London: City \& Guilds Centre for Skills Development.

McWilliam, H. O. A., \& Kwamena-Poh, M. A. (1975). The Development of Education in Ghana (pp. 94). Longman.

Merriam, S. B. (1998). Qualitative Research and Case Study Applications in Education. Jossey-Bass.

Moran, K. (2019, August 10). Gold-producing Countries: Gold Mining in Ghana. Gold Investmenting Network. http:// investing news.com/ daily/resource-investing/precious-metals-investing/gold-investinggold-mining-in-ghana/

Morrow, W. (2007). Learning to teach in South Africa. HSRC Press.Mouzakitisa, G. S. (2010). The role of vocational education and training curricula in economic development. Procedia Social and Behavioral Sciences, 2, 39143920.

Opoku-Asare, N. A., Agbenatoe, W. G., \& deGraft-Johnson, K. G. (2014). Instructional strategies, institutional support and student achievement in general knowledge in art: Implications for visual arts education in Ghana. Journal of Education and Practice, 5(21), 121.

Poku, J. G. (2013). Educational sector reforms in Ghana: A reviewed. Global Research Journal of Education, 3(2), 2031.

Trochim, W. (2019, November 12). What is Evaluation? The Research Methods Knowledge Based (2nd ed.). http://www. socialresearchmeth ods.net/kb/evaluation.php. 